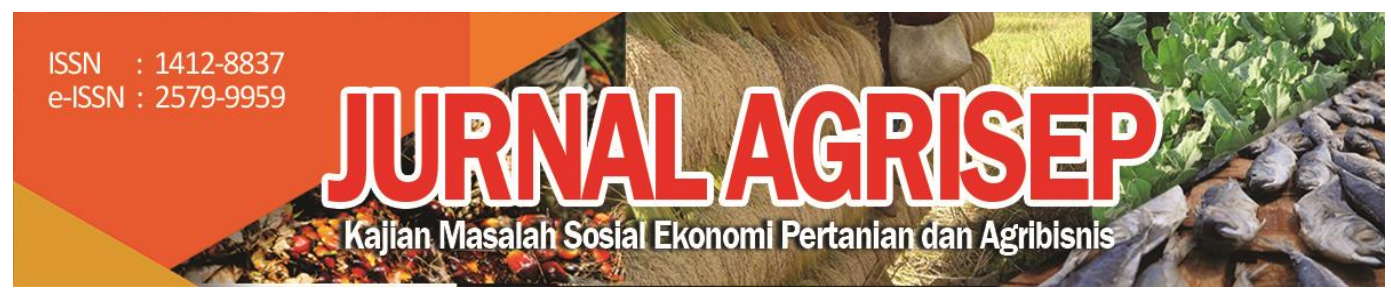

DOI: 10.31186/jagrisep.20.1.179-194

\title{
PROFIL BISNIS STARTUP VIRGIN COCONUT OIL MEMANFAATKAN BUSINESS MODEL CANVAS (BMC)
}

\section{Business Profile of Virgin Coconut Oil Startup Manufacturing Business Model Canvas (BMC)}

\author{
Ayu Wulandary $\triangle_{1)}$; Fitriani R2), Hartina ${ }^{3)}$ \\ 1,2,3) Program Studi Agribisinis, Fakultas Sains dan Teknologi, Universitas \\ Muhammadiyah Sidenreng Rappang \\ Email:ayuwulandary916@gmail.com
}

\begin{abstract}
The business of the Bulowattang village women farmer group is a business that makes herbal oil or known as VCO. VCO is products that have many benefits in terms of health and beauty. Therefore, this business is able to compete with other products and is able to develop rapidly in the future. According to the results of this research, using the canvas business model, it has displayed comprehensive business activities, visible from each business model elements that have described all business activities in the vco business of the Bulowattang Village women's group that will be implemented.
\end{abstract}

Keywords: Business Model Canvas, Local Plants, VCO

\begin{abstract}
ABSTRAK
Bisnis kelompok wanita tani Desa Bulowattang merupakan bisnis yang membuat minyak herbal atau bisa dikatakanVCO. Produk VCO merupakan produk yang memiliki banyak manfaat baik dari sisi kesehatan dan kecantikan. Maka dari itu usaha ini mampu bersaing dengan produk lain serta mampu berkembang pesat kedepannya. Menurut hasil penelitan ini dengan memakai model bisnis kanvas telah menampilkan aktivitas bisnis yang komprehensif nampak dari tiap elemen- elemen model bisnis yang telah menggambarkan semua aktivitas bisnis pada usaha vco kelompok wanita Desa Bulowattang yang akan di terapkan. Sehingga dari hasil kesimpulan penelitian ini bahwa dengan menerapkan model bisnis canvas pada usaha vco, di harapkan mampu memberikan strategi apa saja yang harus disiapkan.
\end{abstract}

Kata kunci :Model Bisnis Canvas, Tanaman Lokal, VCO 


\section{PENDAHULUAN}

Menurunya inovasi bisnis sebagai kasus utama dalam mengalami permaslahan yang terjadi dunia usaha baik bsnis kecil maupun skala menengah. Hingga usaha yang sudah menjadi pengusaha terkenal usaha yang baru merintis. Untuk memaksimalkan inovasi dan kreatifitas bisnis menjadi salah satu tantangan terbesar bagi setiap lingkungan perusahaan sendiri karena setiap bisnis di upayakan dalam mengoptimalkan inovasi kreatifitas bisnis ini sebagai tantangan terbanyak untuk tiap perusahaan itu sendiri. Peningkatan produktifitas perlu diiringi dengan penjualan hasil panen perkebunan rakyat melalui pengolahan pascapanen, sehingga penjualan tidak berupa bahan mentah melainkan produk setengah jadi ataupun produk siap konsumsi, Deswantari (2015). Kabupaten sidenreng rappang, Desa Bulowattang memiliki potensi Desa yang cukup potensial. Hal ini menunjukkan bahwa memiliki banyak tumbuhan kelapa yang kurang dimanfaatkan menjadi tambahan pendapatan ekonomi di Desa Bulowattang. Kelompok wanita yang ada di Desa Bulowattang, membuat suatu produk inovatif yang bermanfaat bagi pendapatan ekonomi masyarakat di sekitarnya. Membuat olahan bahan baku utamanya yaitu buah kelapa. Minyak kelapa murni (Virgin Coconut Oil) dari Indonesia sudah mendunia, bahkan pasarnya sudah diekspor ke negara arab saudi. Hal ini menunjukkan bahwaminyak kelapa murni atau Virgin Coconut Oil sangat di gemari oleh seluruh dunia. Kandungan yang ada di minyak kelapa biasa sangatlah berbeda dengan minyak Virgin Coconut Oil yang di buat oleh kelompok wanitaDesa Bulowattang sangatlah berbeda, hal ini karena tanpa melalui proses pemanasan, penyuligan, pemutihan serta pengharuman minyak.

Hal ini menunjukkan kandungan dan komposisi minyak VCO tidak berubah dari sifat asli yang dimilikinya. Maka dari itu VCO mulai diminati oleh banyak masyarakat sebab manfaat dan kegunaanya minyak VCO lebih banyak di bandingkan minyak kelapa biasa. Adapun manfaat yang dimiliki minyak VCO yaitu, 1. Mempertajam fungsi kongnitif anak, 2. Melancarkan sistem pencernaan, 3. Merawat rambut, 4. Membantu menurunkan berat badan, 5 . Mengurangi frekuensi kejang, 6. Mendukung sistem kekebalan tubuh, 7. Mencegah dan menyamarkan bekas stretchmark buat ibu hamil, 10. Bermanfaat untuk kesehatan kulit serta melembabkan, 11. Menyembuhkan luka lebih cepat. Dirjen perkebunan kementan Kasdi Subagyono mengatakan, ekspor produk perkebunan Indonesia bisa berdaya saing jika pasarnya diperluas. Sejauh ini, produk VCO termasuk salah satu produk terbesar yang diekspor salain minyak goreng kelapa, gula kelapa, kopra, arang dan produk kelapa lainnya.

Pasar VCO kedepan akan terbuka lebar dan tentunya dengan mempertimbangkan gaya hidup masyarkat dunia yang terus meningkat. Pola hidup ini menyebabkan kebutuhan akan makanan dan minuman sehat termasuk organic health oil juga meningkat. Dari sisi harga, VCO lebih murah dari virgin olive oil (VOO), upaya memperluas akses pasar produk VCO juga harus 
ditingkatkan dengan melihat peluang- peluang dalam perundingan kerja sama perdagangan. Menurut data Badan Pusat Statistik (BPS), pada 2019 ekspor kelapa Indonesia sebesar 1,87 juta ton atau senilai 890 juta, ekspor terbesar ke Malaysia sebesar 421 ribu ton, Tiongkok sebesar 358 ribu ton.

Usaha virgin coconut oil ini merupakan usaha yang akan dirintis oleh kelompok wanita di Desa Bulowattang, dengan melihat potensi desa yang ada. Dengan hal ini mengajarkan untuk membuat produk yang inovatif dengan bahan baku dari kelapa sehingga memiliki nilai tambah yaitu menjadi VCO. Produk VCO diharapakan dapat menjadi solusi dalam mengurangi angka pengangguran serta dapat membantu meningkatkan pendapatan rumah tangga khususnya di Desa Bulowattang. Maka dari itu terciptalah ide untuk mengembangkan usaha VCO ini menjadi usaha yang kreatif dan inovasi di eranya. Tentunya dalam menjalankan usaha sangat penting memiliki ilmu pengetahuan bagaimana cara mengelolah usaha secara baik dan mampu bersaing dengan pesaing lainnya. Walaupun penciptaan produk yang baik, tetapi tidak didukung dengan adanya modl bisnis yang tepat akan mengalami kesulitan dalam mengembangkan bisnis yang mereka rintis dengan harapan mampu bertahan. Bukan hanya berfokus pada produk baru saja, tetapi produk yang telah tersedia di pasaran tetap perlu melakukan evaluasi model bisnis yang mereka terapkan secara berskala.

\section{METODE PENELITIAN}

\section{Alat dan Bahan}

Alat yang digunakan dalam penelitian ini kuesioner dan beberapa alat yang mendukung dalam pengambilan data bisnis model kanvas. Bahan yang dipakai dalam penelitian yaitu produk VCO dalam kemasan.

\section{Metode Pengolahan Data}

Penelitian ini metode yng dilakukan adalah metode deskriptif dengan pendekatan studi kasus. Metode penelitian deskriptif digunakan untuk memperoleh gambaran, penjelasan, dan kondisi yang berkaitan objek penelitian secara fakta akurat dan sistematis. Responden yang akan di tuju adalah kelompok wanita tani sebanyak 2 kelompok berjumlah 25 orang. Dengan melakukan tehnik purposive sampling dalam penentuan responden. Melihat sesuai kriteria yaitu kelompok wanita tani binaan Desa Bulowattang yang telah ditentukan sesuai dengan tujuan penelitian sehingga diharapkan dapat menjawab permasalahan penelitian.Metode yang dipakai yaitu dengan membuat plan business model canvas melalui wawancara dan FGD (focus group discussion) akan dilakukan terhadap kelompok wanita binaan Desa Bulowattang, Kecamatan Pancarijang, Sulawesi Selatanserta dokumentasi. Pertama yang 
dilakukan memetakan model bisnis canvas yang terdiri dari sembilan komponen bisnis yaitu sebagai berikut:

1. Customer segment, adalah penentuan pelanggan atau target pasar produk $\mathrm{VCO}$

2. Value proposition, adalah menjelaskan nilai jual dan manfaat produk VCO

3. Customer relationship, adalah bagaimana membangun hubungan antara penjual dan pembeli VCO

4. Channel, bagaimana pelaku usaha mempromosikan produk VCO

5. Revenue stream adalah apa saja yang di dapatkan dan keuntungan oleh pihak penjual VCO

6. Key resource, adalah persediaan sumber daya produk serta financial untuk keberlangsungan produk $\mathrm{VCO}$

7. Key activities, adalah perlakuan pelaku usaha dalam menjalankan bisnisnya

8. Key partners, adalah membangun kerjasama dalam memasarkan produk $\mathrm{VCO}$

9. Cost structure, adalah administrasi pengeluaran dan pemasukan produk $\mathrm{VCO}$

\section{HASIL DAN PEMBAHASAN}

\section{Profil Bisnis}

Produk VCO merupakan bisnis Startup yang baru dirintis dan akan dibina oleh Program Studi Agribisnis Universitas Muhammadiyah Sidenremg Rappang, yang bermula dari pendanaan PDP Ristekbrin 2020. Usaha ini bertujuan untuk peningkatan kesejahteraan rumah tangga apalagi dengan adanya wabah covid-19 ini sangat berpengaruh terhadap perekonomian. Melihat potensi wilayah yang memiliki banyak kelapa. Sehingga para peneliti hibah PDP dan Program studi Agribisnis, Universitas Muhammadiyah Sidenreng Rappang membuat binaan kelompok wanita yang ada di Desa Bulowattang. Produk VCO sangat cocok untuk di kembangkan kedepannya. Maka dari itu kelompok wanita binaan ini sangat antusias untuk memulai usaha baru dengan menggunakan perencanaan analisa Bussiness Model Canvas. Dengan menggunakan bisnis model canvas memudahkan para calon pelaku usaha untuk merencanakan bisnis yang akan mereka rintis.

Hal ini menjelaskan bahwa Lebih terarah dalam melakukan persiapan apa saja yang akan disiapkan serta di lakukan dalam proses pelaksanaan bisnis, dengan harapan dan tujuan yang akan di capai sesuai target serta mampu meningkatkan penjualan dan mempromosikan produk secara baik. Mampu beradaptasi dengan pelaku usaha yang lainnya serta mampu bertahan tehadap faktor internal dan eksternal perusahaan. Dari 9 elemen yang tersedia pada model bisnis canvas, mampu memberikan dan menjelaskan strategi apa saja yang bisa di gunakan dalam mengaplikasikan usaha VCO binaan kelompok 
wanita Desa Bulowattang. Tetapi setelah adanya pengaplikasian dari ke 9 elemen model bisnis canvas yang di rancang dalam usaha binaan kelompok wanita tani, hasil dari implementasi model akan berubah sesuai apa tujuan yang diinginkan dengan melihat keadaan pasar terhadap produk. Selain penggunaan analisis SWOT, evaluasi model bisnis juga dapat dilakukan dengan berdasarkan perspektif konsumen, seperti yang diterapkan pada penelitian Abdurrahman (2015).

Dengan melihat prospek penjualan dipasar sangat menjanjikan untuk membantu meningkatkan pendapatan rumah tangga. Produk VCO ini bukan hanya bagus dalam prospek penjualan, tetapi dari sisi kesehatan dan kecantikan pun sangatlah berguna. Karena salah satu fungsi produk VCO dalam kesehatan adalah dapat menurunkan tingkat kolestrol pada tubuh serta pada fungsi kecantikan untuk melembabkan, menghaluskan kulit dan rambut. Proses pengolahannya pun secara alamiah dan tidak di menggunakan bahan kimia apapun. Jadi uasaha produk VCO yang akan dirintis oleh kelompok wanita Desa Bulowattang ini akan memberi dampak yang baik. Menurut Boedianto (2015) Business Model Canvas dapat menjadi pendekatan yang mudah diimplementasikan oleh organisasi bisnis dalam upaya meakukan evaluasi dan perubahan atau pembenahan dan pengembangan terhadap model bisnis perusahaan sehingga tercipta model bisnis baru yang lebih tepat dan sesuai untuk diaplikasikan oleh perusahaan.

\section{Business Model Canvas}

Model bisnis memiliki beragam definisi berdasarkan pendapat para pakar. Osterwalder dan Pigneur (2015), sebuah model bisnis menggambarkan pemikiran tentang bagaimana organisasi menciptakan, memberikan, dan menangkap nilai. Menurut Wulandary (2018), Bagi seorang wirausaha, inovasi merupakan salah satu faktor yang penting dalam membuat rencana kedepan, menerapkan kreatifitas dalam rangka memecahkan persoalan dan menangkap peluang serta kemauan dalam mengambil risiko untuk menghasilkan produk yang brsaing. Model rencana pengembangan strategi usaha yang akan diimplementasikan pada produk VCO oleh binaan kelompok wanita Desa Bulowattang, Kecamatan Pancarijang, Kabupaten Sidenreng Rappang.

\section{Value propotion}

Value proposition merupakan satu keunikan yang menentukan mengapa produk atau jasa tersebut pantas dipilih oleh pelanggan. Ini memberikan tawaran untuk memecahkan masalah pelanggan atau semaksimum mungkin memenuhi keinginan pelanggan. Keunikan yang ditawarkan harus memberikan tonjolan yang berbeda di bandingkan bisnis pesaing dan di dambakan oleh konsumen. Nilai produk yang akan ditawarkan oleh usaha binaan kelompok wanita Desa Bulowattang berdasarkan hasil penelitian sebagai berikut: 
Tabel 1. Business Model Canvas Produk VCO Kelompok Wanita Desa Bulowattang

\begin{tabular}{|c|c|c|c|c|}
\hline Key Partners & Key Activities & $\begin{array}{c}\text { Value } \\
\text { Propositions } \\
\end{array}$ & $\begin{array}{c}\text { Customer } \\
\text { Relationships }\end{array}$ & $\begin{array}{l}\text { Customer } \\
\text { Segments }\end{array}$ \\
\hline Influencers & Produksi & $\begin{array}{l}\text { Oil herbal yang } \\
\text { praktis }\end{array}$ & $\begin{array}{l}\text { Edukasi } \\
\text { Keunggulan } \\
\text { Produk }\end{array}$ & Ibu rumah tangga \\
\hline Klinik Bidan & $\begin{array}{l}\text { Branding } \\
\text { Knowladge }\end{array}$ & $\begin{array}{l}\text { Murni 100\% } \\
\text { kelapa }\end{array}$ & Friendly Serve & Semua umur \\
\hline Pemerintah & $\begin{array}{l}\text { Pemberdayaan } \\
\text { Petani }\end{array}$ & Produk Lokal & Loyalitas & Konsumen diet \\
\hline & Promosi & & Channels Youtube & \\
\hline & Key Resources & & Channels & \\
\hline & Financial & & Media Sosial & \\
\hline & $\begin{array}{l}\text { Kebun budidaya } \\
\text { tanaman kelapa }\end{array}$ & & $\begin{array}{l}\text { Market Place(E- } \\
\text { market) }\end{array}$ & \\
\hline & Networking & & & \\
\hline & \multicolumn{2}{|c|}{ Cost Structure } & \multicolumn{2}{|c|}{ Revenue Stream } \\
\hline & \multicolumn{2}{|l|}{ Bahan Baku } & \multicolumn{2}{|c|}{ Profit Penjualan Produk } \\
\hline & \multicolumn{2}{|l|}{ Operasional } & \multicolumn{2}{|l|}{ Dana Investasi } \\
\hline & \multicolumn{2}{|c|}{ Biaya gaji karyawan } & & \\
\hline & \multicolumn{2}{|l|}{ Biaya Produksi } & & \\
\hline
\end{tabular}

Sumber: Data Primer, 2020

\section{Oil herbal (VCO)}

Produk binaan kelompok wanita Desa Bulowattang merupakan produk oil herbal yang bahan bakunya dari buah kelapa murni dan VCO ini melalui proses penyaringan dan fermentasi secara alamiah tanpa menggunakan bahan kimia apapun. Sehingga produk VCO ini menyehatkan dan praktis dalam penyajiannya. Produk ini memiliki fungsi yang cukup banyak baik dari sisi kesehatan maupun kecantikan. Kandungan VCO ini mampu menurunkan tingkat kolestrol pada tubuh.

\section{Inovasi produk}

Produk VCO ini merupakan produk yang berinovasi dalam memanfaatkan potensi lokal yang ada di Desa Bulowattang yaitu dari buah kelapa, bahan bakunya yang mudah didapat. Sehingga dalam proses pembuatannya pun secara sederhana dan alami. Proses penyulingannya cukup berhati-hati, dikarenkan kualitas VCO tetap terjaga sehingga dikonsumsi dan tidak efek samping untuk jangka panjang. Tingkat kesterilan pun dijaga agar produk bertahan lama dalam penyimpanan. 


\section{Produk lokal}

Nilai lokal yang dimaksud adalah bahan baku yang tersedia langsung di wilayah proses produksi VCO yang di gunakan dalam pembuatan produk tersebut. Secara tidak langsung dapat memanfaatkan sumber daya alam yang memiliki nilai jual.

\section{Customer segments}

Melakukan pencarian target pasar yang dilakukan oleh binaan kelompok wanita Desa Bulowattang dalam menentukkan pelanggan dan pengguna produk VCO agar memiliki konsumen yang berkelanjutan. Hal ini sangat penting dalam menjalankan usaha, untuk mengetahui konumen seperti apa yang akan kita targetkan terhadap produk yang ingin kita pasarkan. Sebagai berikut hasil penelitian yang telah dilakukan di lapangan.

IRT

Salah satu target konsumen produk VCO adalah Ibu rumah tangga, hal ini di karenakan target konsumen telah menyadari akan pentingnya kesehatan. Serta memiliki peran penting dalam anggota keluarganya, sehingga mampu memberikan arahan serta memiliki nilai tertinggi dalam penentuan keputusan. Melihat secara fakta bahwa ibu rumah tangga memiliki aktivitas kegiatan yang cukup banyak. Sehingga tidak sempat dalam memanjakan dirinya dengan kesalon. Maka dari itu produk VCO ini sangat cocok untuk target konsumen yaitu ibu rumah tangga. Produk VCO dapat memberikan solusi yang baik salah satunya dalam perawatan kulit.

\section{Semua Umur}

Mengapa semua umur karena hal ini menunjukan bahwa produk VCO tidak memiliki keterbatasan dalam pengunaannya. Balita sampai orang tua pun bisa menggunakan produk tersebut. Baik dari sisi kesehatan serta perawatan tubuh. Penggunaan pada balita memberikan sensasi hangat serta melembutkan pada kulitnya. Sedangkan penggunaan pada orang dewasa sampai orang tua yang mengidap penyakit kolestrol pada tubuhnya, setelah mengkonsumsi produk VCO ini berfungsi untuk menurunkan kadar kolestrol. Dengan melihat komposisi yang digunakan pada produk VCO yang akan dirintis oleh kelompok wanita Desa Bulowattang, tidak menggunakan bahan kimia. Bisa dikatakan produk VCO ini alami dari bahan baku yang fresh.

\section{Diet}

Melihat kembali manfaat dan fungsi kegunaan produk VCO yaitu salah satunya dapat menurunkan berat badan. Dengan mengkonsumsi produk secara rutin mampu memberikan efek terhadap tubuh konsumen yang ingin 
melakukan program diet. Walaupun pada saat awal penggunaan VCO pada tubuh terjadi mual, hal ini menunjukkan bahwa fungsi VCO pada tubuh telah bekerja mendetox dari dalam tubuh. Mengeluarkan racun-racun dalam tubuh.

\section{Channels}

Channel adalah elemen yang menyatakan bagaimana organisasi berkomunikasi dengan pelanggan segmenya dan bagaimaan cara menyampaikan nilai suatu produk yang mereka tawarkan kepada calon pelanggannya. Kemampuan pelaku usaha dalam mempromosikan produkVCO. Dengan tujuan agar produk VCO ini dikenal dan mampu bersaing dengan produk-produk lainnya. Adapun saluran promosi produk VCO dengan melalui sebagai berikut:

\section{Sosial Media}

Sosial media mampu memberikan pengaruh terhadap target pasar yang diinginkan sehingga perusahaan memiliki kesempatan untuk menjalin interaksi antara produk yang di pasarkan dengan konsumen melalui sosial media untuk melakukan komunikasi secara dua arah. Sosial media yang akan di gunakan dalam mempromosikan barang atau produk VCO binaan kelompok wanita Desa Bulowattang yaitu melalui Instagram, Facebook, WhatsApp, dan Website Desa Bulowattang. Dengan adanya sosial media, pelaku usaha berharap dapat meningkatkan penjualan serta mampu di kenal di kalangan masyarakat. Pemasaran melalui media sosial saat ini merupakan bentuk pemasaran dengan pertumbuhan tercepat di antara pemasaran media digital lainnya (Kotler 2016). Walaupun demikian, pemasaran secara tradisional juga masih sangat relevan untuk dilakukan, maka dari itu mengintergrasikan pemasaran digital dan tradisional akan memberikan dampak yang maksimal bagi perusahaan (Kotler 2016).

Era digitalisasi 4.0 ini sangat memudahkan para pelaku usaha dalam mempromosikan produk yang mereka jual yaitu melalui sosial media. Dengan melakukan promosi produk di sosial media sangat cepat menarik perhatian konsumen di luar sana. Informasi yang tercantum pada sosial media dengan menggunakan caption yang lucu dan unik serta memberikan gift terhadap konsumen yang membeli produk VCO lebih dari 5 botol. Dengan cara seperti itu dapat menarik perhatian para pengguna instagram untuk mengunjungi halaman instagram produk VCO binaan kelompok wanita Desa Bulowattang.

Selanjutnya menggunakan aplikasi via facebook mempromosi produk karena memiliki fitur dalam penjualan produk di aplikasi facebook. Contohnya grup makassar dagang, grup tersebut berisi orang yang bertujuan untuk mempromosikan produknya. Mempermudah pelaku usaha dalam 
penjualan dan promosi garang yang mereka pasarkan. Aplikasi facebook ini sangat banyak yang menggunakan, baik dari umur bawah sampai orang tua. Maka dari itu berharap dengan mengshare produk VCO di halaman facebook dapat menarik pelanggan membeli produk VCO.

Pada aplikasi whatsapp sangat membantu dalam mepromosikan produk VCO kepada target pasar. Dimana dalam aplikasi whatsapp sangat banyak group-group yang dibuat, sehingga bisa melakukan promosi produk dengan dua arah secara cepat.

\section{Aplikasi e-Market}

E-market merupakan aplikasi yang mempertemukan antara penjual dan pembeli secara online yang bertujuan untuk memperluas jaringan target konsumen, sehingga dapat meningkatkan penjualan produk VCO. Contohnya aplikasi shoope dan tokopedia, produk VCO akan di masukan di dalam aplikasi tersebut. Dengan harapan produk ini mampu di kenal serta banyak yang tertarik. Aplikasi e-market ini sangat bermanfaat pada usaha baru merintis. Hal ini di karenakan bahwa anggota yang mengikuti aplikasi tersebut sudah jutaan orang. Sehingga mampu membantu penjualan produk.

\section{Customer Relationships}

Pembinaan hubungang dengan pelanggang bertujuan untuk mendapatkn pelanggn baru atau mempertahankan pelanggan lama dan menawarkan produk atau jasa lama dan baru pada pelanggang lama. Maka dari itu sangat penting dalam hal pembinaan hubungan antara pelanggan untuk keberlangsungan usaha produk VCO binaan kelompok wanita tani Desa Bulowattang. Layanan komunikasi pada pelangga dapat dimanfaatkan sebagai wadah penyaluran informasi dalam pemenuhan hak pelanggan (Sumarwan 2006). Relasi loyalitas pelanggan dan komunikasi sudah terbukti saling mempengaruhi satu sama lain seperti yang dilakukan pada penelitian mengenai Customer Relationship Management oleh Iriandini (2015).

\section{Pengetahuan keunggulan produk}

Produk VCO merupakan produk yang memiliki manfaat yang banyak. Tetapi banyak pula masyrakat masih awam terhadap fungsi produk VCO ini. maka dari itu butuh adanya edukasi dan pengenalan tentang produk VCO serta apa saja keunggulan yang terdapat pada produk VCO kelompok wanita tani binaan di Desa Bulowattang. Sehingga produk ini dapat diterima oleh masyarakat dengan tujuan untuk meningkatkan penjualan.

\section{Ramah pelayanan}

Pelayanan yang diberikan kepada konsumen produk VCO sangat mementingkan dari sisi kenyamanan dalam memasarkan produk ke 
konsumen.Sehingga konsumen tersebut nyaman dalam berkomunikasi tentang produk yang mereka inginkan. Salah satu cara memikat pelanggan atau konsumen agar tertarik terhadap pada produk kita yairu bagaimana cara penjual memberikan edukasi tentang produk VCO ini secara baik dan ramah terhadap calon konsumen. Maka dari itu dalam proses penjualan bukan hanya kualitas produk saja yang di perhatikan tetapi etika dalam berdagang memasarkan produknya.

\section{Loyalitas}

Mampu membangun hubungan emosional secara baik dengan konsumen maka dibangunlah sikap loyalitas dalam berkomunikasi secara langsung maupun tidak langsung. Adapun pendekatan secara personal yang dilakukan seperti dengan pemberian kartu ucapan pada saat pembelian produk VCO. Saat konsumen berinteraksi secara langsung dengan pelayanan servis pada aplikasi chat dan media sosial dimana kegiatan interakasi tersebut dimanfaatkan untuk memanfaatkan teknologi sehingga dapat terjalin interkasi langsung konsumen secara banyak.

Interaksi yang dilakukan yaitu memperhatikan konten seperti apa yang digunakan dalam mengunggah produk yang ingin dipasarkan. Misalnya pemberian caption serta detail keterangan pada produk. Sehingga para konsumen mengetahui informasi tentang produk VCO tersebut. Channel Youtube

Pada jaman digitalisasi memanfaatkan media sosial seperti Youtube saat ini banyak digunakan kepentingan dalam bisnis, sehingga hal ini menjadi peluang untuk bisnis produk VCO dalam binaan kelompok wanita Desa Bulowattang untuk dikenalkan kepada masyarakat. Konten youtube berisi berisi bagaimana pentingnya menjaga kesehatan serta merawat kulit secara alami akan keunggulan dari bahna baku utama dalam produk serta proses penyulingan yang secara alamiah dan steril.

\section{Revenue Stream}

Adapun beberapa cara dalam mendapatkan keuntungan dari penjualan produk atau biaya financial dalam pembuatan produk VCO yang berkelanjutan dari setiap segmen konsumen yaitu dengan penjualan aset, biaya penggunaan, biaya berlangganan, pinjaman (Osterwalder \& Pigneur, 2010). Dengan hal seperti ini pelaku usaha mampu menyusun atau memanajemenkan aliran keuangannya dari mana saja. Bertujuan mampu bertahan dalam melakukan penjualan produk VCO binaan Desa Buloeattang.

\section{Profit Penjualan Produk}

Usaha produk VCO kelompok wanita tani binaan Desa Bulowattang didapatkan dari hasil penjualan produk VCO yang akan diputar menjadi 
modal dan keuntungan dalam penjualan produk, dalam hal ini mampu memberikan keberlangsungan dalam melakukan penjualan produk. Penjualan adalah suatu kegiatan yang mengharuskan perusahaan mengeluarkan sejumlah barang dan jasa baik secara tunai maupun kredit, sehingga menghasilkan sejumlah finansial (Irawati, 2008).

\section{Modal awal}

Pada awal usaha VCO ini di jalankan, memiliki dana investasi. Dana awal yang diperolehnya dari Ristekdikti yang kemudian dana awal tersebut di jadikan modal awal, dalam mendirikan usaha VCO ini. walaupun dana awal yang tidak terlalu banyak. Untungnya pada persiapan bahan baku, kelompok wanita Desa bulowattang memanfaatkan potensi lokal yang ada di wilayah proses produksi VCO. Sehingga mampu meminimalisirkan biaya bahan baku. Maka dari itu tidak terlalu banyak menggunakan modal biaya dalam proses penjualan. .

\section{Key Activities}

Dalam melakukan kegiatan bisnis hal yang sangat penting di perhatikan adalah bagaimana strategi model bisnis yang diterapkan oleh pelaku usaha. Apakah mampu memberikan nilai unggul dalam mempromosi suatu produk yang akan di pasarkan ke calon konsumen. Sehingga calon konsumen dapat menarik perhatian terhadap produk yang mereka tawarkan. Pelaku usaha mampu menjangkau target pasar dan mampu menjaga pasar produk. Aktivitas lain adalah kolaborasi. Kolaborasi dengan mitra meruapakn hal yang perlu di lakukan untuk meningkatkan kinerja perusahaaan. Dengan berintegrasi dengan mitra diharapkan akan meningkatkan efesiensi, efektifitas, kualitas, serta meningkatkan keunggulan kompetitif untuk maisng-masing perusahaan yang terlibat (Kansil 2015).Adapun Kegiatan yang akan dilakukan oleh pelaku usaha kelompok wanita tani Desa Bulowattang adalah sebagai berikut:

\section{Produksi}

Proses produksi VCO di lakukan secara berurutan dari proses penyediaan bahan baku VCO sampai proses pengemasan produk. Hal ini sangat di jaga setiap prosesnya. Agar tetap terjaga kualitas produk yang dipasarkan. Sehingga tidak mengecewakan para pelanggan atau calon konsumen.

\section{Brand produk}

Brand merupakan icon suatu produk, maka dari itu brand sangatlah penting terhadap produk yang ingin kita pasarkan. Fungsinya untuk memberikan daya tarik kepada konsumen dan pelanggan. Sebelum pemberian brand terhadap produk, pelaku usaha wajib memiliki 
pengetahuan bagaimana carnya brand tersebut mampu di kenal dan mudah di ingat selalu oleh konsumen yang melihatnya. Sehingga ada daya tarik tersendiri pada produk VCO kelompok wanita tani Desa Bulowattang dibandingkan dengan produk VCO lainnya. Maka dari itu edukasi dalam pemberian brand produk sangatlah penting. Produk VCO harus mampu menciptakan brand yang kuat karena dapat menjadi nilai keunggulam kompetitif dalam jangka panjang bagi perusahaan untuk berkembang (Aaker 2014).

\section{Memberdayakan petani}

Pemberdayaan petani yang dilakukan oleh pelaku usaha bertujuan untuk meminimalisrkan biaya bahan baku pengolahan VCO serta biaya distribusi pengangkutan pun sedikit mengurangi. Dengan memanfaatkan pemberdayaan petani kita dapat membantu pula warga setempat dalam meningkatkan pendapatannya.

\section{Promosi}

Promosi adalah peranan yang penting untuk berjalannya perusahaan start up yang masih belum dikenal oleh pasar, dimaana tujuan daari promosi yaitu agar customer segments atau konsumen tersegmentasi mengenal produk dan berniat untuk membeli produk yang dipromosikan. Promosi produk VCO yang dilakukan dengan cara mengikuti bazar dan mengikuti kegiatan yang di lakukan oleh desa. Penyebaran informasi produk VCO melalui dari mulut ke mulut masyarakat. Serta penyebaran brosur ke dinas- dinas setempat. Dengan ini memudahkan produk cepat dikenal dan dapat bersaing dengan produk lainnya.

\section{Key Resource}

Kemampuan pelaku suaha dalam persediaan bahan baku dan financial terhadap perusahaan yang dijalankan saat ini. Dimana persediaan bahan baku mampu mempertahankan nilai keunggulan pada produk VCO yang di jual. Key resource dapat berupa fisik, intelektual dan finansial. Tanpa orang-orang yang memiliki keahlian yang mumpuni pada masing-masing bidang maka tidak akan mudah bagi sebuah perusahaan untuk berkemabang (Samsudin 2005).key resource yang dimiliki oleh bisnis VCO kelompok wanita tani Desa Bulowattang adalah sebagai berikut:

\section{Financial}

Hal ini sangat penting dalam menjalankan usaha terhadap persediaan bahan baku dan keberlangsungan produk dalam eksistensinya. 


\section{Kebun budidaya tanaman kelapa}

Kebun budidaya tanaman kelapa merupakan bahan baku utama yang harus disediakan untuk dapat mengefisienkan biaya bahan baku utama.

\section{Networking}

Selain financial, jaringan bisnis dalam lingkup luas sangat diperlukan. Hal ini memudahkan pelaku usaha mendapatkan dukungan dengan jaringan pelaku usaha lainnya. Salah satunya yaitu dapat membantu investasi dana ataupun membantu promosi produk VCO Dengan banyaknya jaringan usaha yang bekerja sama dengan perusahaan kita, semakin memudahkan memperkenalkan produk VCO.

\section{Key Partners}

Jaringan dari supplier dan mitra yang membuat model bisnis bekerja. Aliansi berasal dari luar perusahaan yang dapat mensuplai dan mendukung dalam menciptakan, mengantarkan dan menangkap nilai perusahaan produk VCO. Adapun beberapa mitra yang menjadi bagian dari bisnis VCO kelompok wanita tanii Desa Bulowattang adalah sebagai berikut :

\section{Selebgram}

Di era digitalisasai ini banyak memberi warna pada pelaku usaha. Contohnya di dalam sosial mediabisa dikatakan Celebrity endorser atau selebgram dapat dijadikan salah satu mitra kita untuk memperkenalkan produk VCO kelompok wanita tani dengan penyampaian nilai produk kepada target pasar kita. Teman mitra kita ini dapat memberikan informasi tentang keunggulan pada produk VCO kelompok wanita Desa Bulowattang, Dengan cara dan gaya yang unik. Sehingga dengan seperti itu mampu memberikan daya tarik pada konsumen.

\section{Klinik bidan}

Klinik bidan sangat cocok untuk di jadikan tempat supplier mengapa karena di tempat tersebut merupakan tempat berkumpulnya banyak orang khsusnya ibu- ibu dan balita. Dengan melihat fungsi dan kegunaan minyak VCO ini sangat cocok untuk di kalangan tersebut.

\section{Pemerintah}

Pemerintah disini sangat berperan penting, momentum serta akses terhadap pemberian kebijakan-kebijakan, selain itu pemerintah sering mengadakan kegiatan untuk pengusaha pemula dalam mengenalkan brand serta produknya seperti pameran dan ajang persaingan antar produk lainnya. 


\section{Cost Structure}

Struktur biaaya menggambarkan semua biaya yang muncul sebagai akibat dioperasikannya model bisnis ini. semua upaya mewujudkan nilai keunggulan produk cvo yang di buat oleh kelompok wanita tani Desa Bulowattang. Struktur biaya dipengaruhi oleh strategi perusahaan yang dipilih, apakah mengutamakan biaya rendah atau menguatamakan biaya rendah atau mengutamakan manfaat istimewa.

\section{Penyediaan bahan baku VCO}

Dalam proses penyediaan bahan baku VCO, memerlukan dana yang tidak terlalu banyak. Hal ini dikarenakan bahwa bahan baku telah tersedia pada tempat produksi. Sehingga dapat meminimalisirkan biaya bahan baku.

\section{Operasional}

Biaya operasional pada usaha VCO kelompok wanita Desa Bulowattang terdiri dari biaya pengeluaran bahan baku, biaya produksi, biaya promosi produk, serta biaya gaji karyawan

\section{Biaya gaji karyawan}

Biaya yang dikeluarkan untuk memberi upah keoada tenaga kerja harian atau bulanan pada usaha VCO kelompok wanita Desa Bulowattang.

\section{Biaya produksi}

Biaya produksi biaya yang dikeluarkan untuk pembelian proses produksi produkVCO, diantaranya adalah biaya pembelian bahan baku sampai proses pengemasan produk.

\section{Biaya pemasaran}

Pemasaran proses kemasyarakatan di mana individu dan kelompok memperoleh apa yang mereka butuhkan dan inginkan dedngan menciptakan, menawarkan, dan secara bebas mempertukarkan produk dan jasa yang bernilai dengan orang lai. (Kotler 2009). Biaya pemasaran diataranya biaya pembuatan brand produk serta fasilitas alat dan bahan untuk mempromosikan produkVCO. pemasaran dan promosi untuk menyampaikan nilai keunggulan produkVCO oleh kelompok wanita tani Desa Bulowattang, sehingga biaya pemasaran menjadi hal yang penting bagi bisnis pemula dalam memasarkan produk dalam berkelanjutan. 


\section{SIMPULAN}

\section{Simpulan}

Berdasarkan hasil penelitian dengan melihat profil bisnis kelompok wanita tani Desa Bulowattang yang dibina oleh program studi agribisnis yaitu menggunakan Business Model Canvas terlihat bahwa bisnis VCO yang dirintis oleh kelompok wanita tani Desa Bulowattang memiliki peluang untuk dikembangkan terlihat dari nilai keunggulan produk yang ditawarkan yaitu oil herbal yang praktis serta memiliki banyak fungsi baik dari segi kesehatan dan kecantikan. Lalu target pasar konsumen yang dituju yaitu ibu rumah tangga yang dapat mempengaruhi anggota keluarga agar dapat mementingkan kesehatan untuk jangka panjang. Semua umur dapat mengkonsumsi atau menggunakan produk VCO ini, baik balita sampai lansia. Memiliki fungsi menurunkan kolestrol bagi penderita kolestrol. Serta balitapun dapat menggunakan minyak VCO ini. Konsumen diet yang bertujuan untuk mengurangi kadar gula dalam tubuh yang mengakibatkan obesitas atau kegemukan. Denganadanya produk VCO ini dapat membantu para konsumen yang ingin diet serta melek terhadap hidup sehat.

Sedangkan strategi dalam mempromosikan produk VCO dengan menggunakan sosial media, e- market, klinik bidan, dan penyuluhan serta pameran. Adapun hubungan yang dibangun oleh pelaku usaha dengan konsumen yaitu yang dibangun dengan informasi pengetahuan keunggulan produk, pelayanan servis, loyalitas terhadap konsumen. Untuk Key activities yaitu produksi, pengetahuan dalam membranding produk, memberdayakan petani lokal, promosi produk. Sedangkan Key Resourceyaitu financial, kebun budidaya tanaman kelapa, dan networking untuk keberlanjutan usaha. Key Partners, bagaimana pelaku usaha membangun kerjasama dengan stakeholder yang mampu membantu usaha VCO, yaitu diantranya adalah influencer atau komunitas, klinik bidan dan pemerintah. Sedangkan untuk cost structure yang dikeluarkan oleh bisnis kelompok wanita tani Desa Bulowattang yaitu bahan baku, operasional, biaya gaji, biaya produksi dan biaya pemasaran produk.

\section{DAFTAR PUSTAKA}

Abdurrahman A. 2015. Perancangan model bisnis produk minuman rosella dengan lidah buaya (Studi Kasus UMKM B\&G Grup Bogor). [skripsi]. Bogor (ID): Institut Pertanian Bogor.

Aaker D. 2014. Aaker on Branding. Eta Sitepoe, penerjemah. Jakarta (ID): PT Gramedia Pustaka Utama. Terjemahan dari: Aaker on Branding.

Badan Pusat Statistik Sulsel. 2018."PDRB Provinsi Sulawesi Selatan atas Dasar Harga Konstan 2019 Menurut Lapangan Usaha(Juta Rupiah),2015- 
2020." Melalui https://www.sulsel.bps.go.id (diakses pada Agustus 2020).

Badan Pusat Statistik Nasional. 2019." Ekspor kelepa di Indonesia". Melalui https://www.bpsnasional.go.id (diakses pada Agustus).

Boedianto LP, Harjanti D. 2015. Strategi Pengembangan Bisnis Pada Depot Selaris Dengan Pendekatan Business Model Canvas. AGORA [internet]. [diunduh pada 2020 November 05]; 3(2): 292-301.

Deswantari, N.W. (2015). Strategi Peningkatan Nilai Tambah Komoditas Perkebunan di Kabupaten Bogor Cianjur dan Sukabumi [skripsi]. Bogor (ID): Institut Pertanian Bogor.

Goenawan, F. (2008). Nilai dan Gaya Hidup Masyarakat di Dalam Media. Jurnal Ilmiah SCRIPTURA. 2(2): 183-190.

Iriandini A, Yulianto E, Mawardi M. 2015. Pengaruh Customer Relationship Management (CRM) Terhadap Kepuasan Pelanggan dan Loyalitas Pelanggan. Jurnal Administrasi Bisnis. 23 (2): 2-7.

Irawati, Susan. 2008. Akuntansi Dasar 1 \& 2. Bandung : Penerbit Pustaka.

Kansil F, Pondaag J. 2015. Evaluasi Kolaborasi Relation Partnership dalam Aktivitas Logistik pada Komoditas Cengkeh di Desa Toloarane. Jurnal Ekonomi, Manajemen, Bisnis, Administrasi. 3 (2): 78-90.

Kotler. P. dan Keller K.L.2009. Manajemen Pemasaran. Jilid 1. Jakarta : Erlangga

Kotler P, Armstrong G. 2016. Principles of Marketing 16th Edition. England (UK): Pearson Education Limited.

Osterwalder \& Pigneur, (2005). Business Model Generation. New Jersey: John Wiley \& Sons, Inc.

Osterwalder, A dan Pigneur, Y. (2010). Business Model Generation : A Handbook for Visionaries, Game Changers dan Challangers. New Jersey : John Wiley \& Sons, Inc.

Osterwalder A, Pigneur Y. (2015). Business Model Generation. Jakarta (ID): PT Elex Media Komputindo (Terjemahan).

Rahmatulloh R. 2018. Strategi Pengembangan usaha Perikanan di KK farm Kabupaten Bogor dengan Pendekatan BMC [skripsi]. Bogor (ID): Institut Pertanian Bogor.

Samsudin S. 2005. Manajemen Sumber Daya Manusia. Bandung (ID): CV Pustaka Setia.

Sumarwan U. 2006. Peran Ilmu Konsumen dalam Peningkatan Kesejahteraan Melalui Pemenuhan Hak atas Informasi. Bogor (ID): FEMA IPB.

Syafira R. 2017. Strategi Pengembangan Inti Agrowisata dengan pendekatan Business Model Kanvas [skripsi]. Bogor (ID): Institut Pertanian Bogor Wulandary, A., Burhanuddin dan WB., Priatna. (2018). Kinerja Wirausaha dan Orientasi Kewirausahaan Pelaku UMKM Olahan Abon Ikan. AGRISEP 17(2): 129 - 138. 